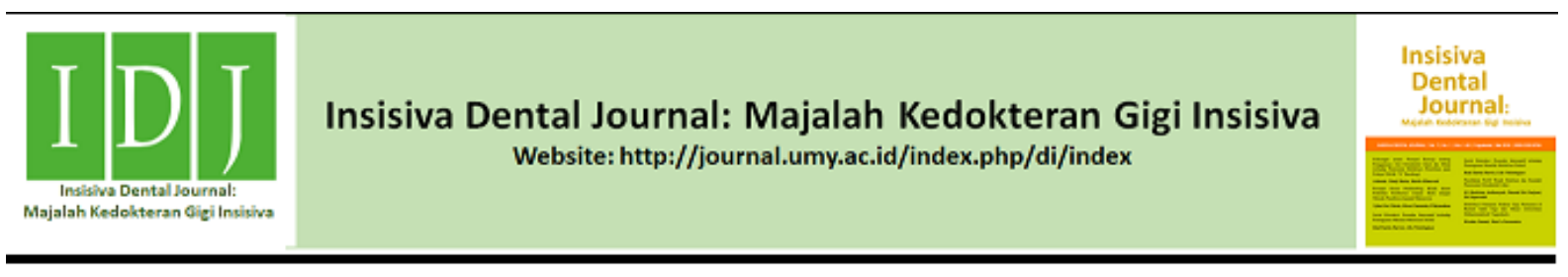

Case Report

\title{
Perawatan Crown Lengthening pada Gigi Anterior Pasca Terjadi Fraktur
}

Crown Lengthening Treatment in Anterior Teeth Post Fracture

\section{Fauziah Karimah', Hartanti ${ }^{2}$,*}

${ }^{1}$ Program Studi Kedokteran Gigi, Fakultas Kedokteran dan Ilmu Kesehatan, Universitas Muhammadiyah Yogyakarta, Jalan Brawijaya, Tamantirto, Kasihan, Bantul, Indonesia.

${ }^{2}$ Departemen Periodonsia, Program Studi Kedokteran Gigi, Fakultas Kedokteran dan Ilmu Kesehatan, Universitas Muhammadiyah

Yogyakarta, Jalan Brawijaya, Tamantirto, Kasihan, Bantul, Indonesia.

Received date: Mei 25 2 st 2018; reviewed date: June $7^{\text {th }}, 2018$; revised date: August $28^{\text {th }}, 2018$; accepted date: October $11^{\text {st }}, 2018$ DOI : $10.18196 /$ di. 7298

\begin{abstract}
Abstrak
Fraktur gigi anterior yang parah akibat trauma sering menyisakan sedikit struktur gigi yang menjadi tantangan dokter gigi untuk merestorasi. Retensi yang minimal memungkinkan terjadinya kegagalan restorasi, sehingga kebanyakan dokter akan lebih memilih melakukan pencabutan. Crown lengthening adalah prosedur pembedahan untuk mengekspose mahkota klinis yang tersisa sebagai usaha untuk meningkatkan retensi restorasi. Tujuan laporan kasus ini adalah untuk mengevaluasi hasil restorasi pasca dilakukan crown lengthening. Laporan kasus seorang perempuan usia 20 tahun mengalami fraktur gigi anterior maksila pasca kecelakaan yang dialaminya 2 minggu lalu. Gigi 21 fraktur dengan garis patahan horizontal 1/3 servikal mengenai pulpa. Status periodontal baik dan tidak ditemukan kelainan pada gambaran radiograf. Penatalaksanaan dilakukan scalling dan root planning pada regio gigi 21 sebelum pembedahan. Gingiva dipotong sedalam $2 \mathrm{~mm}$ pada seluruh permukaan menggunakan blade nomor 15 dilanjutkan penutupan luka bekas pembedahan dengan periodontal dressing. Perawatan saluran akar dilakukan dan diikuti dengan restorasi pasak fiber serta inti dengan resin komposit. Porcelain fused to metal diinsersikan sebagai restorasi mahkota akhir. Hasil restorasi akhir gigi 21 menunjukkan retensi yang memadai untuk restorasi mahkota porcelain fused to metal. Mahkota yang diinsersi dapat bertahan setelah 6 bulan observasi dan pasien merasa cukup puas dengan hasil perawatan. Kesimpulan dari kasus ini, prosedur crown lengthening dapat menunjang restorasi akhir yang retentif pada kasus fraktur gigi anterior yang kehilangan sebagian besar struktur mahkota.
\end{abstract}

Kata Kunci: Bedah periodontal; Crown lengthening; Gigi anterior

\begin{abstract}
Anterior tooth fracture that left minimal tooth structure might be dilemmatic for the dentist to make a restoration. Since it has less retention for the final restoration, dentists usually decide to extract the teeth without considering its aesthetics aspect. Crown lengthening is a procedure to expose clinical crowns that may enhance retention in the final restoration. The purpose of this study was to evaluate a restoration result after the crown lengthening procedure. The case reported 20 years old woman who came to the dental hospital with a fracture in the upper incisive after a motorbike accident. Teeth 21 was fractured into 1/3 cervical without periodontal tissue damage. The pulp was necrosed, and there was no periapical disorder from radiograph imaging. Case management by scaling and root planning in region 21 was done before the surgery. Gingival of teeth 21 was incised circumferentially about $\pm 2 \mathrm{~mm}$ in depth using blade no 15 and universal curettage while the surgical wound was covered with a periodontal pack. Root canal treatment was done, followed by fiber post and composite resin core restoration. At last, porcelain fused to a metal crown was inserted for the final restoration. Result: Final restoration of porcelain fused to the metal crown remained until six months of observation, and the patient was satisfied with the result of the treatment. The conclusion is that the crown lengthening procedure can be beneficial to create more retention for final restoration in fracture anterior teeth with less tooth structure.
\end{abstract}

Keywords: Periodontal surgery; Crown lengthening; Anterior teeth

\footnotetext{
* Corresponding author, e-mail: hartanti@umy.ac.id
} 


\section{PENDAHULUAN}

Crown lengthening adalah suatu prosedur reseksi periodontal yang memiliki tujuan menghilangkan sebagian jaringan pendukung periodontal untuk menambah terbukanya mahkota klinis gigi. Ini adalah prosedur yang lazim dilakukan pada beberapa indikasi perawatan restoratif. ${ }^{1}$

Kasus yang sering ditemukan oleh dokter gigi adalah mahkota klinis yang pendek karena karies, erosi, malformasi, fraktur, atrisi, pengurangan gigi berlebih, erupsi yang tidak sempurna, eksostosis dan variasi genetik. Panjang mahkota klinis yang pendek harus dinaikkan atau dipanjangkan ketika karies atau margin dari gigi yang fraktur berada pada subgingiva, sehingga mahkota gigi dapat memiliki retensi dengan restorasinya. ${ }^{2}$ Crown lengthening merupakan prosedur pembedahan untuk memberikan retensi mahkota yang memadai. ${ }^{3}$

Crown lengthening digolongkan pembedahan estetik, hal ini dilakukan untuk meningkatkan estetik pada gigi anterior maksila atau untuk untuk menyediakan struktur gigi yang adekuat untuk retorasi yang baik. Crown lengthening meliputi beberapa teknik diantaranya gingivektomi atau gingivoplasti, prosedur flap apikal dan bisa melibatkan resesi tulang dan mendorong erupsi gigi dengan atau tanpa fiberotomi. ${ }^{4}$ Pada kasus poket dengan kedalaman $5 \mathrm{~mm}$ atau lebih pada gingival yang berkeratin, prosedur gingivektomi diperlukan. ${ }^{3}$

Dalam melakukan Crown lengthening memerlukan beberapa pertimbangan diantaranya aspek biologis dan anatomi giginya. Pada aspek biologis perlu memerhatikan dimensi antara puncak tulang alveolar crest dan batas free gingiva. Dimensi rata-rata 2,75 - 3,00 mm. Batas restorasi tidak boleh lebih dari $3 \mathrm{~mm}$ dari puncak alveolar crest. Jika lebih akan menyebabkan inflamasi, iritasi marginal gingiva, ketidaknyamanan pasien, mudah berdarah, estetik buruk, dan jaringan periodontal rusak. Pada aspek anatomi gigi perlu memerhatikan panjang dan bentuk dari akar crown and root ratio, akar tidak boleh terekspos berlebihan maksimal $3 \mathrm{~mm}$ dari Cemento Enamel Junction (CEJ), ketinggian dari furkasio, smile line (gigi anterior), adanya interdental space, posisi bibir apakah terdapat hipertonus otot, hipermobilitas bibir. ${ }^{5}$

Pada kasus fraktur dengan sisa struktur gigi minimal yang membuat retensi minimal memungkinkan terjadinya kegagalan restorasi, sehingga kebanyakan dokter akan lebih memilih melakukan pencabutan, namun crown lengthening sebagai usaha yang cukup jarang dilakukan untuk meningkatkan retensi restorasi menjadi menarik untuk dipelajari.

\section{LAPORAN KASUS}

Pasien perempuan usia 20 tahun mengalami fraktur gigi anterior maksila pasca kecelakaan yang dialaminya 2 minggu lalu. Pemeriksaan ekstraoral tidak ada kelainan, pada pemeriksaan intraoral terlihat gigi 21 fraktur dengan garis patahan horizontal 1/3 servikal dengan pulpa terbuka. Status jaringan periodontal baik dan status kebersihan gigi (OHI) baik dengan indeks plak dan kalkulus yang minimal. Gingiva berwarna pink, konsistensi kenyal dan teksturnya stipling. Probing depth minimal dan tidak ada mobilitas gigi pada gigi 21 .

Penatalaksanaan pada kasus ini perlu memperhatikan aspek periodontal dan aspek restoratif. Prosedur pembedahan crown lengthening akan dilakukan untuk mengoptimalkan hubungan antara jaringan periodontal, gigi dan restorasi yang akan dibuat.

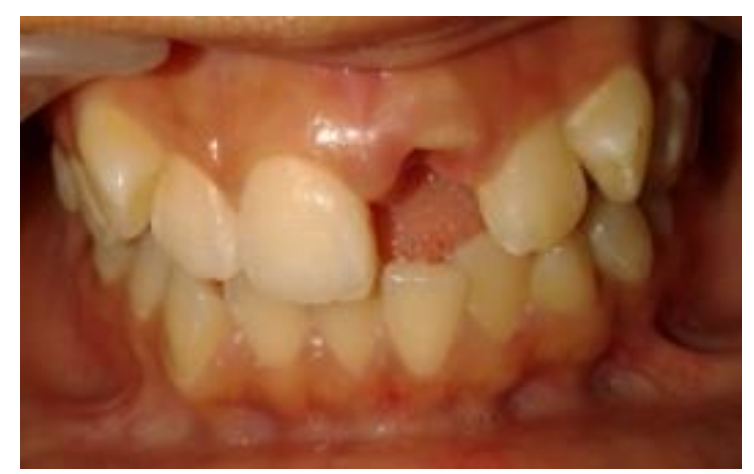

Gambar 1. Sebelum crown lengthening 
Sebelum melakukan proses pembedahan dilakukan scalling dan root planning pada gigi 21 dan pada region gigi anterior. Insisi dengan blade no 15 pada semua permukaan gigi 21 dengan kedalaman $\pm 2 \mathrm{~mm}$ dari margin gingival, kuretase dilakukan untuk membantu menghaluskan gingival setelah diinsisi. Daerah luka diirigasi dengan salin yang dicampur dengan povidon iodin, dan dilanjutkan penutupan area luka dengan periodontal dressing. Follow up dilakukan 1 minggu setelahnya, periodontal dressing dibuka dan dilakukan irigasi menggunakan campuran salin dan povidon iodin.

Restorasi dilakukan setelah 2 minggu pasca pembedahan dimana fase remodeling gingival pasca pembedahan tercapai. Restorasi rebuild up menggunakan GIC RMGI Fuji 2 LC yang sebelumnya telah dilakukan retraksi gingival menggunakan silk dan larutan adrenalin. Dilakukan perawatan saluran akar pada gigi tersebut dengan teknik stepback dan diisi dengan gutta perca dan endametason sebagai sealer. Follow up dilakukan setelah 1 minggu pasca pengisian saluran akar. Saluran akar hermetic dan tepi tumpatan dengan margin gingival terlihat baik. Dilanjutkan dengan pemasangan pasak Fiber fabricated dan core build up dengan Resin composite solare-x A3, dan pemasangan mahkota jaket porcelain fused to metal untuk restorasi akhirnya.

\section{PEMBAHASAN}

Prosedur pembedahan crown lengthening membantu dalam restorasi pada gigi yang memiliki karies yang luas maupun fraktur yang menyisakan sedikit struktur gigi. ${ }^{2}$ Crown lengthening ini bertujuan untuk mengekspos mahkota klinis yang pendek untuk tujuan restorasi. ${ }^{4}$ Dalam proses pembedahan perlu memperhatikan aspek biologi dimana perlu memerhatikan dimensi antara puncak tulang alveolar crest dan batas free gingiva. Dimensi rata-rata 2,75 - 3,00 mm. Batas restorasi tidak boleh lebih dari $3 \mathrm{~mm}$ dari puncak alveolar crest. Jika lebih akan menyebabkan inflamasi, iritasi marginal gingiva, ketidaknyamanan pasien, mudah berdarah, estetik buruk, dan jaringan periodontal rusak. ${ }^{5}$ Penyembuhan luka setelah pembedahan crown lengthening harus diperhatikan. Waktu penyembuhan yang optimal adalah 6 minggu samapai 6 bulan, tetapi jika akan dilakukan perawatan restorasi lebih baik dilakukan pada tahap remodeling awal dengan tetap mengobservasi tahap penyembuhan luka pasca pembedahan. ${ }^{6}$ Selain itu kebersihan mulut dan kebiasaan-kebiasaan pasien seperti merokok dan minum makan yang panas setelah pembedahan perlu diperhatikan, sehinga tidak mengganggu tahap penyembuhan luka. ${ }^{7}$

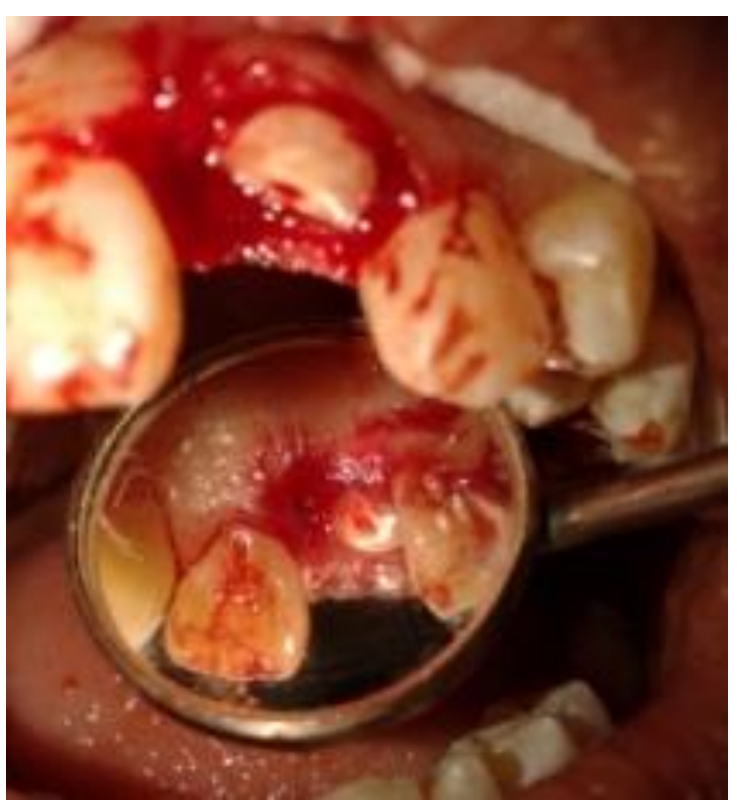

Gambar 2. Setelah pembedahan.

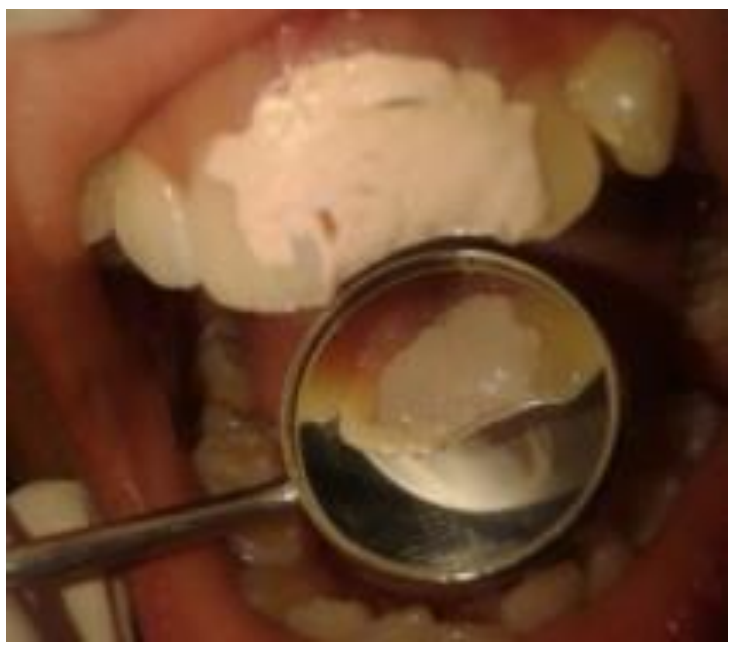

Gambar 3. Aplikasi periodontal dressing 
Gambar 4. Gigi 21 setelah 1 minggu pasca pembedahan

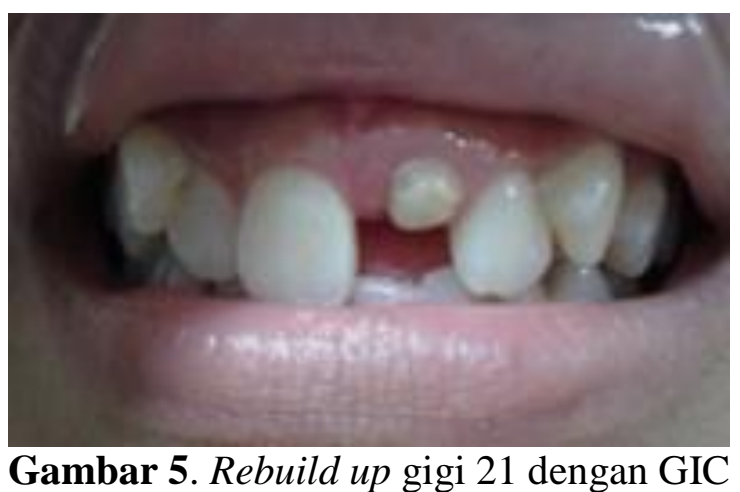

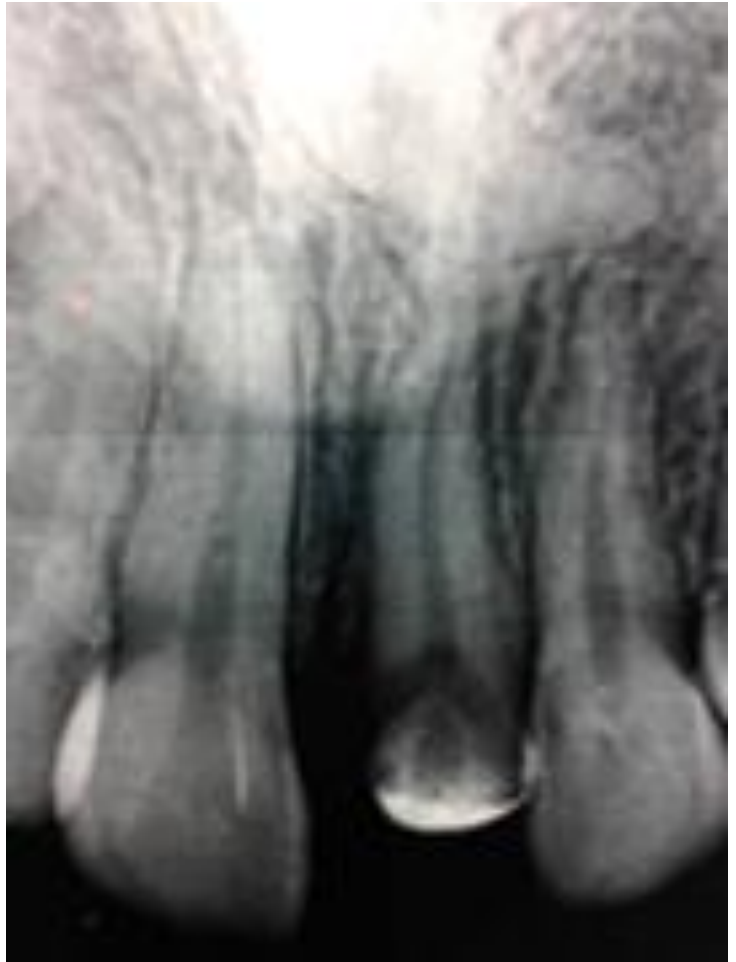

Gambar 6. Foto rontgen setelah rebuild up

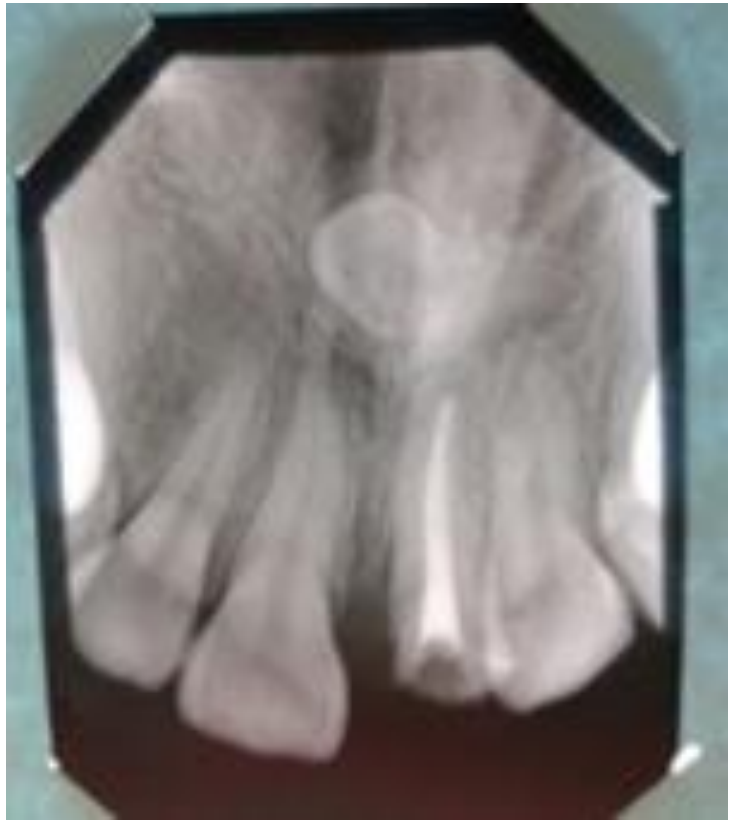

Gambar 7. Perawatan saluran akar terlihat hermetis.

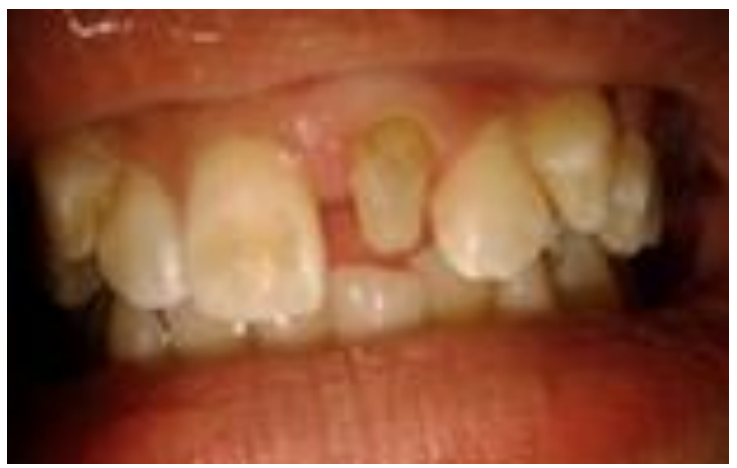

Gambar 8. Pasak fiber dan core build up dengan RK Solare- $x$

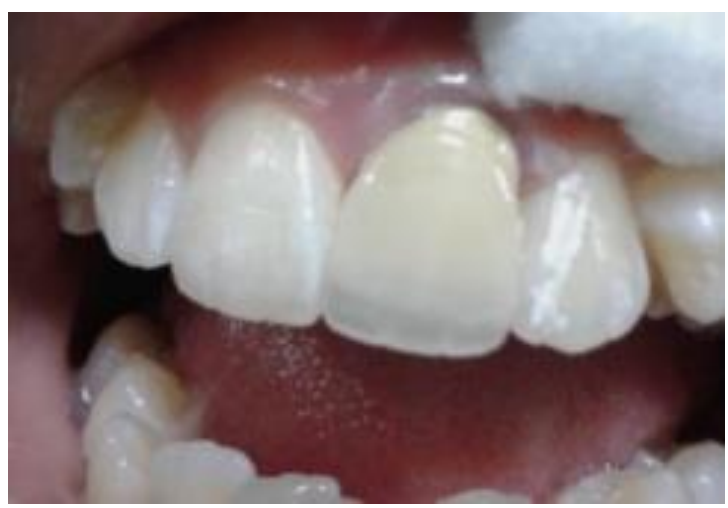

Gambar 9. Mahkota jaket PFM 


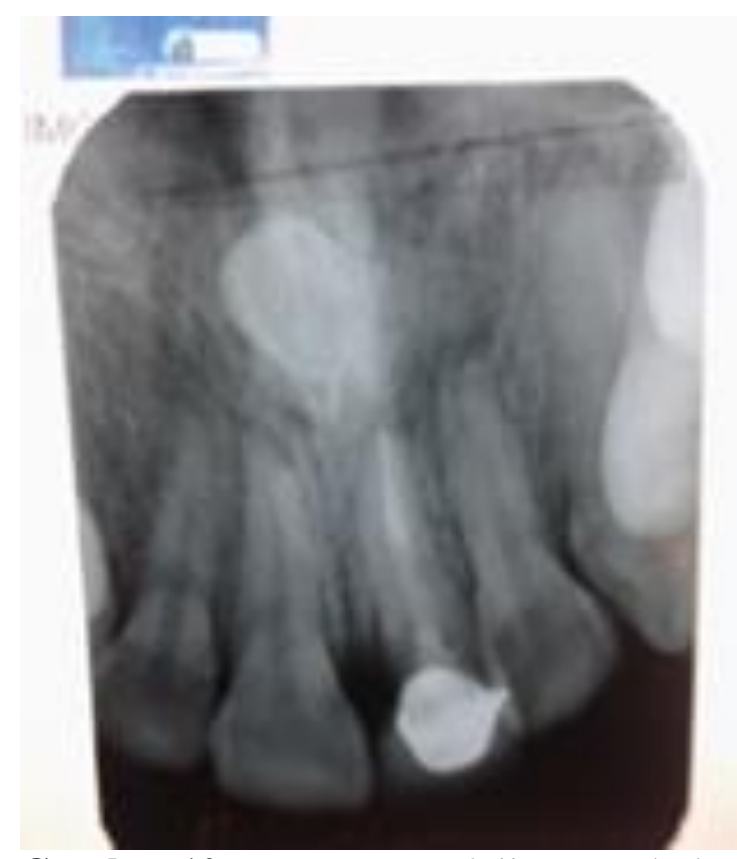

Gambar 10. Foto rontgen follow up 6 bulan

\section{KESIMPULAN}

Crown lengthening sangat bermanfaat untuk membantu membuat restorasi pada gigi yang rusak dan menyisakan struktur gigi yang sedikit ataupun fraktur, sehingga restorasi memiliki retensi yang cukup adekuat pada gigi dan adaptasi dengan jaringan periodontal baik.

\section{DAFTAR PUSTAKA}

1. Danesh-Mayer, Michael. Surgical Crown Lengthening- Building a solid Foundation restoration excellence. Australasian Dental Practice, 2012; 23(4): 58-62.

2. Tomar, N., Bansal, T., Bhandari, M., Sharma, A. The perio-estheticrestoration approach for anterior rehabilitation. $J$ Indian Soc Periodontol, 2013; 17 (4): 535-538.

3. de Oliveira PS, Chiarelli F, Rodrigues JA, Shibli JA, Zizzari VL, Piattelli A, Iezzi G, Perrotti V. Aesthetic Surgical Crown Lengthening Procedure. Case Rep Dent. 2015; 437-412.

4. Milavec S and Gaspirc, B. Case Report: Clinical Crown Lengthening:
Laser-Assisted Versus Conventional surgery therapy. J. LA\&HA, 2014; 2014(1): 42-44.

5. Lai, Jim. Y., Silvestri, L., Girard, B. Anterior Esthetic Crown Lengthening Surgery. J Can Dent Assoc, 2001; 67(10): 600-603.

6. Assaf, M. Esthetic Crown Lengthening for Upper Anterior Teeth: Indications and Surgical Techniques. I J Pre Clin Dent Res, 2014; 1(2): 49-53.

7. Newman, M. G., Takei, H., Klokkevold, P. R., \& Carranza, F. A. Clinical Periodontolgy. Saunders: Elsevier. 2014. 